INTERNATIONAL JOURNAL OF SYSTEMATIC BACTERIOLOGY

Vol. 16, No. 2 April 1966 pp. 197-221

\title{
INDICATOR ORGANISMS-A REVIEW. I. TAXONOMY OF THE FECAL STREPTOCOCCI ${ }^{1}$
}

Paul A. Hartman, George W. Reinbold and Devi S. Saraswat ${ }^{2}$

Departments of Bacteriology and

Dairy and Food Industry

Iowa State University, Ames

ABSTRACT. The terms "enterococci," "fecal streptococci" and "group D streptococci" are discussed and defined. Development of the taxonomy of the fecal streptococci is described. Physiological differences, serology, the chemical basis of serological specificity and some other possible taxonomic approaches are elaborated upon.

\section{INTRODUCTION}

Bacterial classification has recently received great impetus from an increasing desire to learn more about the characteristics of various groups of bacteria and the relationships of these bacteria to one another. Efforts to place classification on a quantitative basis (Sokal and Sneath, 1963) and to discover the genetic interrelationships of various microorganisms (Marmur, Falkow and Mande1, 1963) also have contributed to this revival of interest. Although any one discovery or idea may result in the modification of a classification, the resultant classification is always based on the total quantity of information that has accumulated. Classifications are the result of evolutionary processes. For this reason, it is advantageous periodically to view the

Journal Paper No.J-5120 of the Iowa Agricultural and Home Economics Experiment Station, Ames, Iowa. Projects No. 1050 and 1379. This work was supported in part by U.S. Public Health Service Research Grants EF-00112 from the Division of Environmental Engineering and Food Protection and AI-05219 from the Division of Allergy and Infectious Diseases.

2 Rockefeller Foundation Scholar. Present address: Rajasthan College of Agriculture, Udaipur, Rajasthan, India. 
classification of a group of microorganisms in retrospect.

During the preparation of a series of reviews on indicator organisms in foods (Hartman, Reinbold and Saraswat, 1965), we decided that a summary of the taxonomy of the fecal streptococci was in order (Buchanan, 1958) to form a firm basis for subsequent discussions of media, methods, distribution and significance of these bacteria. An excellent paper on the group D streptococci by Deibel(1964a) appeared after our review had been substantially completed; however, the approaches differed sufficiently that the two reviews should supplement each other.

Because of their distribution and importance, a considerable quantity of work has been done on the physiological, serological and other characteristics of the fecal streptococci. As a result, the fecal streptococci have become one of the better characterized bacterial groups. Many points have been clarified, yet ambiguities still remain. Most of the early studies have been summarized in comprehensive reviews by Orla-Jensen (1919), Dible (1921), Sherman (1937, 1938) and Frost and Engelbrecht (1940). Skadhauge (1950), Seelemann (1954), Shattock $(1955,1962)$ and Niven (1963) have more recently described selected aspects of the fecal streptococci. The reader is referred to these reports and the review of Deibel (1964a) for numerous references omitted from the present review.

\section{Definition of Terms}

The terms 'enterococci,' 'fecal streptococci,' 'group D streptococci,' 'Streptococcus faecalis' and even 'streptococci' have sometimes been used very loosely and interchangeably to designate various food-borne bacteria. These terms are shown in Table 1 . Each term is defined by the species of Streptococcus that it contains. This grouping is similar, but not identical, to the one proposed by Niven (1963).

It is obvious that the term, 'Streptococcus faecalis,' should refer to a specific bacterial species. Furthermore, the term 'streptococci,' is so general that it means very little when used to describe microorganisms isolated from foods. There is no dispute that the serological group D is composed of those streptococci (Table 1) which contain the $D$ antigen. However, the serological group D contains two

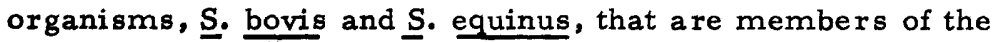
viridans group (Breed, Murray and Smith, 1957). Slanetz 
Table 1. Definition of the terms "enterococci," "group D streptococci" and "fecal streptococci" based on Streptococcus spp. belonging to each group.

Fecal streptococci

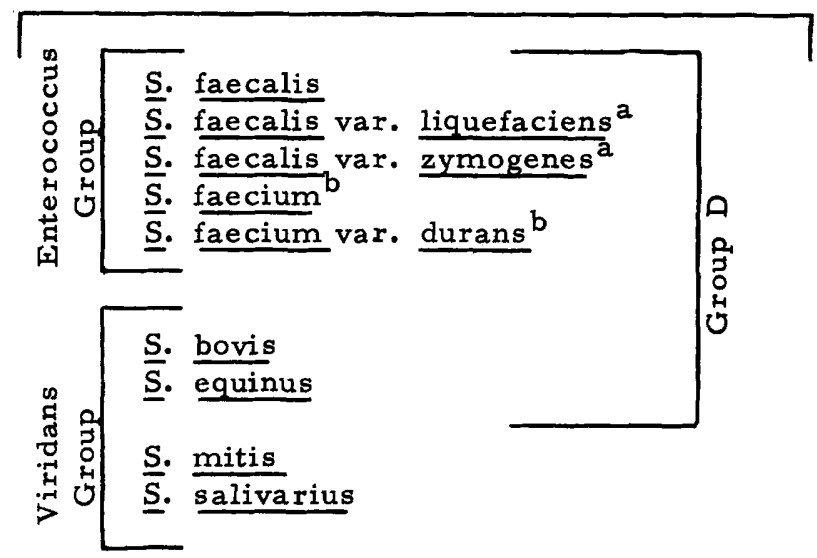

a These two varieties are probably not justifiable. See text for discussion.

b

Streptococus faecium is not recognized in Bergey's Manual of Determinative Bacteriology, 7th ed. (Breed et al., 1957).

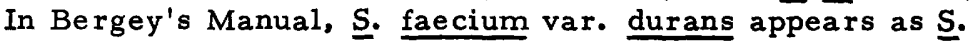
durans.

and Bartley (1957) proposed extension of the enterococcus group to include $\underline{S}$. bovis and $\underline{S}$. equinus, or all organisms belonging to Lancefield's group D (Slanetz and Bartley, 1964). Bartley and Slanetz (1960) thought that all streptococci commonly inhabiting the intestinal tract of animals should be included within the term 'enterococcus.' It would seem wise to us to restrict the term enterococcus to its present usage in Bergey's Manual of Determinative Bacteriology (Breed et al., 1957). Otherwise, the term would require even more extensive broadening to include S. salivarius, which Niven, Smiley and Sherman (1942) found to sometimes compose the predominant streptococcal flora of the human intestine.

Shattock (1955) and Mossell, van Diepen and de Bruin (1957) have suggested that the terms 'enterococci' and 'fecal 
streptococci' should be synonymous. Niven (1963) thought that the term 'fecal streptococci' should be limited to either the enterococci or group D streptococci. The philosophy of Cooper and Ramadan (1955) and Kenner, Clark and Kabler (1960) seems most appropriate to us: to include in the fecal streptococci all Streptococcus spp. consistently present in significant numbers in fresh fecal excreta, when adequate methods for detection of all types present are used. Thus, the terms given in Table 1 would have three definite meanings: one, taxonomical (enterococcus and viridans groups); the second, serological (group D); and the third, sanitary significance (fecal streptococci).

\section{Taxonomy}

Present day taxonomy of the fecal streptococci has developed from earlier studies by many investigators. Thiercelin (1899) first used the term 'enterococcus' to describe, on a morphological basis, a Gram-positive diplococcus of intestinal origin. Andrewes and Horder (1906) called a group of nonhemolytic streptococci, characteristic of bacteria from the human intestine, 'streptococcus faecalis.' In the opinion of Dible (1921), the two names were synonymous, and he suggested that they be applied to a group of heatresistant diplococci commonly found in human feces. OrlaJensen (1919) identified and named two of the se heat-resistant diplococci, $\underline{\text { S. faecium }}$ and $\underline{\mathrm{S}}$. glycerinaceus, without relating them either to the $\underline{S}$. faecalis of Andrewes and Horder (1906) or to the 'enterococcus' described by Thiercelin (1899) and other workers. Sherman (1937) used the term 'enterococcus' to designate a group of streptococci including hemolytic, nonhemolytic and gelatin-liquefying types. He thought

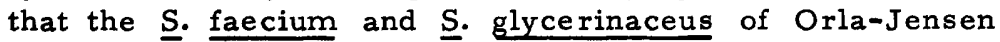
(1919) were both synonymous with the S. faecalis of Andrewes and Horder (1906). Sherman (1937, 1938) regarded the 'enterococcus group' as comprising $\underline{S}$. faecalis and its varieties, liquefaciens and zymogenes, and the $S$. durans of Sherman and Wing $(1935,1937)$. This was the basis for the classification devised by C. F. Niven, Jr. and collaborators for Bergey's Manual of Determinative Bacteriology (Breed et al., 1957). The enterococcus group is catalase negative (Isaacs and Scouller, 1948; see also Whittenbury, 1965a) and shares the criteria of Sherman (1937); i. e., growth at 10 and $45^{\circ} \mathrm{C}$, at $\mathrm{pH} 9.6$, in $6.5 \% \mathrm{NaCl}$ broth, in $0.1 \%$ methylene blue milk, survival at $60^{\circ} \mathrm{C}$ for $30 \mathrm{~min}$ and production of ammonia in peptone broth. 
Streptococcus faecium, Orla-Jensen (1919), was recognized as a synonym of $\underline{S}$. faecalis in the 6th edition of Bergey's Manual (Breed et al., 1948). There is considerable evidence, however, in recent literature to suggest that this species deserves individual recognition. Skadhauge (1950)

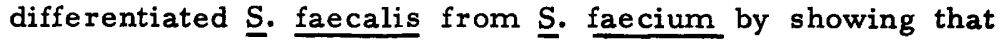
the former organism grows in a medium containing $0.04 \%$ potassium tellurite, whereas growth of the latter organism is inhibited. Barnes (1956a) observed that the two species had different reduction and fermentation reactions. She found that, under appropriate conditions, $\underline{\text { S. faecalis reduced }}$ 2,3,5-triphenyl tetrazolium chloride strongly, while $\underline{\text {. }}$ faecium reduced this compound weakly or not at all. Barnes and Ingram (1955) and Barnes (1956b) reported that $\underline{S}$. faecalis usually produces reduction, acid and coagulation in litmus milk in $24 \mathrm{hr}$, but that $\underline{\mathrm{S}}$. faecium reduces litmus much less rapidly and that sometimes acid production is the only reaction noted. Lake, Deibel and Niven (1957) reported that $\underline{S}$. faecalis and its varieties ferment $a-m e t h y l$ glucoside, citrate, glycerol (anaerobically), melezitose and sorbitol, but do not ferment melibiose and do not require folic acid for growth. Streptococcus faecium and $\underline{S}$. durans both gave diametrically different reactions in all these tests. Furthermore, Deibel and co-workers $(1958,1960,1964)$ found that S. faecalis and its varieties require lipoic acid to obtain energy for growth from citrate, pyruvate and serine, but not when arginine or malate are utilized as energy sources. Deibel (1960, 1964b) also showed that, although all these organisms hydrolyze arginine, only $\underline{S}$. faecalis and its varieties were capable of utilizing arginine as an energy source. London and Appleman (1962) found that, in vigorously aerated glucose-medium cultures, $\underline{S}$. faecalis produced acetic acid and acetylmethylcarbinol in a ratio of $1: 1$, while ratio for. S. faecium was $35: 1$. Hartsell and Caldwell (1961) reported that $\underline{S}$. faecalis and its varieties were lyzed by a combination of lysozyme and trypsin, but not by lysozyme alone;

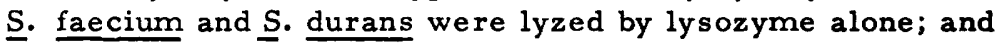
S. by using these and other tests (Deibel, Evans and Niven, 1959; Deibe1, 1964a) have shown that $\mathbf{S}$. faecium deserves status as a distinct species. Barnes $(1964)$ and $W$ hittenbury (1965a) are of the opinion that tellurite resistance and tetrazolium reduction are key differential tests. Whittenbury (1965a) has described still other differential tests.

Several important reports have appeared in the last 5 
years, all indicating that some consolidation and rearrangement of species and varieties within the enterococcus group is desirable. It is interesting that some of the recent suggestions echo sentiments expressed much earlier. For example, Thomson and Thomson, in 1928 (1928-29), mentioned that they had found $\underline{S}$. liquefaciens and $\underline{S}$. zymogenes to be identical. Similar suggestions have been made by recent workers, among which the report of Deibel, Lake and Niven (1963) is of great importance. The key definitive features described by these workers (see also Niven, 1963 and Deibel, 1964a) are given in Table 2. It is our experience that the set of differential tests proposed by these workers is the most appropriate yet suggested. Only two species would be recognized. One species would be composed of $\underline{S}$. faecalis (Andrewes and Horder, 1906; S. glycerinaceus, Orla-Jensen, 1919) and its varieties, liquefaciens (Sternberg, 1892; Long and Hammer, 1936; Mattick, 1949) and zymogenes (McCallum and Hastings, 1899; Mattick, 1949; see also Thomson and Thomson, 1928-29 and Smith, Niven and Sherman, 1938). The second species would be composed of $\underline{S}$. faecium (Orla Jensen, 1919) and its variety, durans (Sherman and Wing, 1935, 1937). Thus, $\underline{S}$. faecium would be recognized as a species and would absorb S. durans as a variety. An arrangement similar in many respects to that just described was proposed by Horie $(1959,1961)$.

Further consolidation has been proposed by Colobert and Morelis (1958; see also Morelis and Colobert, 1958 and Colobert, 1962). These workers had reached similar conclusions regarding the varietal status of $\underline{S}$. durans. In addition, Colobert and co-workers (loc. cit.; see also Colobert and Blondeau, 1962a, $1962 \mathrm{~b}$ and Defayolle and Colobert, $1962)$ reached the conclusion that $\underline{S}$. faecalis was a collective strain (species), in which there were many diverse biotypes or varieties: durans, faecium, innominatus (a new group, originated by the French workers), liquefaciens, proprium (Skadhauge, 1950), and possibly others, such as the S. faecalis var. glycerinaceus of Severi (1942, Hauduroy et al., 1953) and $\underline{S . ~ f a e c i u m ~ v a r . ~ m o b i l i s ~ o f ~ L a n g s t o n, ~ G u t i e ́ r e z ~}$ and Gouma, 1960; Grandal, 1957a, 1957b). The zymogenes variety was thought not to deserve varietal status, a conclusion similar to that expressed earlier by Thomson and Thomson (1928-29), Evans and Chinn (1947), and Hartsell and Caldwell (1961). Hartman and Rouze (unpublished) also failed to obtain satisfactory differentiation of species and

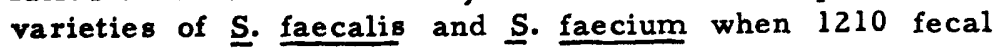


Table 2. Key features in differentiation of $\underline{S}$. faecalis and its varieties, liquefaciens and zymogenes from S. faecium and $\underline{\text { S. durans }}$.

\begin{tabular}{|c|c|c|}
\hline Feature & S. faecalis & S. faecium \\
\hline $\begin{array}{l}\text { Fermentation: } \\
\text { Arabinose } \\
\text { Citrate } \\
\text { Glycerol (anaerobic) } \\
\text { Gluconate } \\
\text { Mannitol } \\
\text { Melezitose } \\
\text { Melibiose } \\
\text { Sucrose } \\
\text { Tetrazolium reduced } \\
\text { Growth, } 0.04 \% \text { tellurite } \\
\text { Folic acid required } \\
\text { Gelatinase, tube method } \\
\text { Strong greening on blood } \\
\text { agar pour plates }\end{array}$ & $\begin{array}{l}- \\
+ \\
U s u a l l y+b \\
U s u a l l y+ \\
+ \\
U s u a l l y+ \\
U s u a l l y- \\
+ \\
U s \text { ually }+ \\
+ \\
- \\
-(\text { liguefaciens }+) \\
-\frac{\text { zymogenes }}{\beta \text {-hemolytic })}\end{array}$ & $\begin{array}{l}+ \text { (durans -) } \\
\text { Usually - } \\
\text { Usually - } \\
\text { Usually - } \\
+ \text { (durans -) } \\
\text { Usually - } \\
\text { Usually + } \\
+(\underline{\text { durans }} \\
\text { usually -) } \\
\text { Usually - } \\
\text { Usually - } \\
\text { Usually + } \\
\text { - } \\
\text { Usually + } \\
\text { (some durans } \\
\beta-\text { hemolytic) }\end{array}$ \\
\hline $\begin{array}{l}\text { a Data from Deibel et al } \\
\text { Table } 1 \text {. } \\
\text { b The term, "usually,". }\end{array}$ & See footno & es (a) and (b) of \\
\hline
\end{tabular}

streptococci from diverse animal and plant sources were examined by a battery of 42 different tests. Many strains, especially those from vegetation (see also Mundt, 1963 and references cited the rein) and foods, possessed sets of characteristics that placed them between established groups. Their results indicated that, if any mutually exclusive set of features was used to delineate a species of enterococcus, variants could be isolated that would fit into neither group (see also Krantz and Dunne, 1965).

Evidently, enterococci may be readily differentiated into well-defined 'species' if all organisms that do not meet the Sherman criteria in entirety are first eliminated from furthe $r$ study and if subsequent tests are limited to a few 'important' features. Under these circumstances, intermediates 
are rarely detected. Thus, Kereluk (1959) studied 307 isolates of enterococci isolated from frozen meat pies. All fulfilled the Sherman criteria. (This is an indication that the isolation procedure used was highly selective). He separated $S$. faecalis and $S$. faecium strains by use of an identification scheme similar to that proposed by Barnes (1956a) and concluded that $\underline{S}$. faecium was a separate and easily distinguishable species of enterococcus deserving independent status. Differentiation of enterococci into well-defined species becomes more difficult when isolates that do not fulfill all the Sherman criteria are subjected to further study. Thus, Kenner et al. (1960) placed such strains in an 'enterococcus biotype' group and Mieth $(1960,1961)$ placed such strains in an 'atypical ente rococcus' group. Burkwall and Hartman (1964) also had to designate an 'atypical enterococcus' group to accommodate many of the strains isolated in their study. (See also Ferraro, 1960.) It is apparent, the refore, that some flexibility of the description of the enterococci is desirable to permit inclusion of many isolates that would not fit into a species when very rigid criteria are used. Caution in this regard also has been expressed by Deibel (1964a). One method of introducing some flexibility would be to specify that a certain number or percentage of features (i.e., 8 or 9 or 10 , or 80 or $90 \%$ ) must be fulfilled for an organism to be designated an enterococcus. Such flexibility will probably be necessary if the criteria suggested by Deibel et al. (1963; Deibel, 1964a) are established for routine speciation, because intermediates exist in nature (Deibel, Lake and Niven, 1959; Barnes, 1964). Identification is complicated further by the failure of some recently isolated strains to yield typical reactions until several transfers have been made in vitro (Mannweiler, 1955; Hartman and Rouze, unpublished). The reason for these anomalous results is unclear, but a possible explanation is offered by the work of Whittenbury (1963).

There is much less controversy that $\mathrm{S}$. bovis (Orla-Jen-

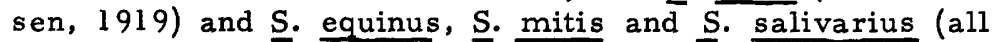
described by Añdrewes and Horder, 1906) are separate species. (See also Engelbrecht, 1935 and Seelemann and Obiger, 1964). The re may eventually be consolidation within these species also because of the many similarities of $\underline{S}$.

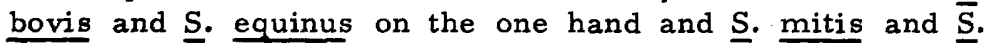
salivarius on the other hand. Most strains of these bacteria grow at $45^{\circ} \mathrm{C}$, but do not share any of the other criteria of Sherman (1937) for enterococci. Streptococcus bovis fer- 
ments lactose and produces acid in litmus milk, whereas S. equinus characteristically does not ferment lactose and produces no apparent reaction in litmus milk. Streptococcus bovis hydrolyzes starch (Dunican and Seeley. 1962), is insensitive to lysozyme systems (Hartsell and Caldwell, 1961) and is the only streptococcal species reported to be capable of using ammonium salts as a sole source of nitrogen for growth (Pres cott, Williams and Ragland, 1959; Wolin, Manning and Nelson, 1959). Smith and Shattock (1962) believed that $\underline{\mathrm{S}}$. bovis and $\underline{\mathrm{S}}$. equinus were distinct species; however, as pointed out by Deibel (1964a), further studies on these two species are necessary to more clearly establish intraspecies boundaries. Streptococcus mitis and $\mathbf{S}$. salivarius (Safford, Sherman and Hodge, 1937) differ from S. bovis in that they are insensitive to $40 \%$ bile and do not hydrolyze starch. (However, amylase-negative strains of $\underline{S}$. bovis have been noted-see, for example, Mieth, 1960). Streptococcus salivarius and $\underline{S}$. mitis are differentiated (She rman, Niven and Smiley, 1943) on the basis of hemolysis of blood, fermentation of inulin and production of mucoid colonies on $5 \%$ sucrose agar by $\underline{\text { S. salivarius. Streptococcus }}$ mitis lacks these three properties.

Williams, Hirch and Cowan (1953) described certain cocci isolated from the air. These bacteria were placed in a new genus, Aerococcus; however, their physiological properties resemble closely tnose of the viridans streptococci. The taxonomic relationships of Aerococcus, as well as members of another genus, Pediococcus, to the fecal streptococci are in need of clarification. (See also Whittenbury, 1965b.)

\section{Serology}

The serological differentiation of fecal streptococci from other streptococci is based on the grouping scheme originated by Irancefield (1933). It soon became evident that $\underline{S}$. faecalis belonged to the serological group D (Lancefield and Hare, 1935; Hare and Maxted, 1935; Shattock and Mattick, 1943). Streptococcus faecalis var. zymogenes also was found to possess group D antigen (Houston, 1936; Sherman, Mauer and Stark, 1937; Smith et a1., 1938), as did S. faecalis var. liquefaciens and S. durans (Sherman, 1938; Graham and Bartley, 1939). When better differentiation between

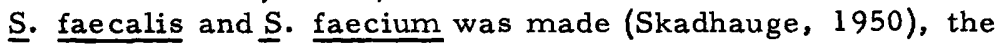
latter microorganism also was found to belong to group D (Skadhauge, 1950; Sharpe and Shattock, 1952). 
Conclusive demonstration of group $D$ antigen in $\underline{S}$. bovis was more difficult; only about half of Sherman's (1938) cul-

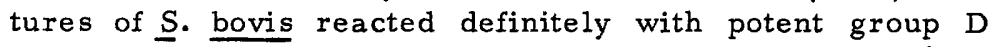
antiserum, and about one-third gave negative results. (See also Shattock and Mattick, 1943.) When improved methods were used for the preparation of antisera and of extracts for precipitin tests, $\underline{S}$. bovis was found to possess group D antigen (Shattock, 1949a; Seelemann and Carstens, 1951). The $\mathrm{D}$ antigen was produced by all strains examined, but was not always extractable with hydrochloric acid, although broken cells always yielded D antigen. Streptococcus equinus was more refractive to serological grouping than $\underline{S}$. bovis. Sherman (1938) had noted that some of his strains of $\underline{S}$. equinus reacted weakly with group $D$ antisera; however, not until recently was this species definitely placed into group D (Smith and Shattock, 1962; Fuller and Newland, 1963).

The other fecal streptococci evidently do not possess group D antigen. Streptococcus salivarius was found by Sherman, Niven and Smiley (1943; see also Shattock, 1949b) to be devoid of group D antigen. Members of this species were subsequently found to possess group $K$ antigen (Williams, 1956; Stewart and McKeever, 1963). Not all strains

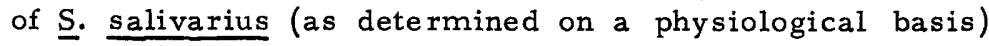
react with group $\mathrm{K}$ antiserum, so additional studies will be necessary to elucidate further antigenic properties of this species. Furthermore, the resemblance of some strains of S. salivarius to certain group D streptococci is so striking (Hartman and Rouze, unpublished data) that it might be profitable to search again for group $D$ antigen in selected strains of this species, using refined techniques. Such combinations of antigens are not unprecedented: Sharpe (1952) noted that a common type-antigen was present in both a strain of $\underline{S}$. lactis and a strain of $\underline{S}$. faecium which would allow them to react with both group $\bar{D}$ and group $N$ antisera. (See also Lancefield, 1941; Perry and Briggs, 1955; Perry Newland and Briggs, 1958). In addition, Smith and Shattock (1964) observed that group $Q$ streptococci (Guthof, 1955) possessed both group $Q$ and group $D$ antigens. As far as we

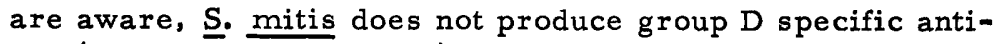
gen (Sherman et al., 1943), but re-examination of members of this species, and even of Aerococcus spp. (Williams et al. , 1953) might be warranted now that improved techniques have been developed.

Using preparations of type-specific antisera, Sharpe and Shattock (1952) designated 24 serological types within the 
group D streptococci. Sharpe's (1952) serological type of S. faecium became number 25; 14 new types described by Sharpe and Fewins (1960) were added to the previous list, making a total of 39 se rological types in group D. Further revision of the typing scheme was suggested by Sharpe (1964), based on the recommendation of Lancefield (Williams and Wilson, 1963). Many different serological types of $\underline{\mathbf{S}}$. bovis also exist (Medrek and Barnes, 1962a). Stewart añd McKeever (1963) have subdivided the group $\mathrm{K}$, containing S. salivarius. Therefore, it is apparent that many serological subgroups can be obtained within the fecal streptococci. In 1949, Shattock (1949b) predicted that the re were more serological types than had been reported within the group $D$ at that time. The three broad divisions proposed by her within the group D on physiological grounds (viz. , S. faecalis and its varieties; $\underline{S}$. faecium and $\underline{S}$. durans; and $\underline{S}$.

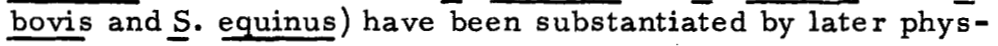
iological and serological studies. Her arrangement of species is markedly similar to the one recently proposed by Deibel et al. (1963).

Additional serological studies on the group D streptococci have been made by Jones and Shattock (1960), Papavassiliou (1962), Barnes (1964) and others. Their findings have generally supported the conclusions drawn by Shattock (1949); refer to these papers for details of these investigations. Deibel (1964a) has precisely summarized the development of methodology in serological analyses of group $D$ streptococci; papers by Kunter (1963) and Bleiweis, Karakawa and Krause (1964) are the only contributions in this area that have appeared subsequent to Deibel's review. Details of methodology will not be elaborated upon in the present review except to mention that Medrek and Barnes (1962a) reported that some group D streptococci, when grown under certain conditions, did not yield hydrochloric acid extracts which would react serologically with group D antisera. This phenomenon had also been observed by other workers. Cultural conditions conducive to production of the group $D$ antigen were elucidated by Medrek and Barnes (1962b).

\section{Chemical Basis of Serological Specificity}

Lancefield (see Niven et al., 1964) suggested that there was sufficient information now available to place serological classification of enterococci on a chemical basis (Table 3). 
Table 3. Chemistry of the antigenic components of Lancefield's serological types. ${ }^{a}$

\begin{tabular}{|c|c|c|}
\hline Group & Group Specific Antigens & Chief Component \\
\hline A & Cell wall polysaccharide & $\begin{array}{l}\text { Rhamnose }+ \\
\text { glucosamine }\end{array}$ \\
\hline $\mathrm{B}$ & Cell wall polysaccharide & $\begin{array}{l}\text { Rhamnose }+ \\
\text { glucosamine }\end{array}$ \\
\hline $\mathrm{C}$ & Cell wall polysaccharide & $\begin{array}{l}\text { Rhamnose }+ \\
\text { galactosamine }\end{array}$ \\
\hline $\mathrm{D}$ & Intracellular ${ }^{\mathrm{b}}$ teichoic acid & $\begin{array}{l}\text { Glucosyl- } \\
\text { glycerophos phate }\end{array}$ \\
\hline$G$ & Cell wall polysaccharide & $\begin{array}{l}\text { Rhamnose }+ \\
\text { galactosamine }+ \\
\text { galactose }\end{array}$ \\
\hline $\mathrm{N}$ & Intracellula $\mathbf{r}^{\mathrm{b}}$ teichoic acid & $\begin{array}{l}\text { Galactosyl- } \\
\text { glycerophosphate }\end{array}$ \\
\hline$F$ & ancefield (1964 & al. , 1964). \\
\hline
\end{tabular}

This suggestion was founded on studies made by several investigators in the last decade on location of the group $D$ antigen in the cell and the antigenicity and chemical composition of cellular fractions.

Interest in the exact location of group $D$ antigen was stimulated greatly when Elliott $(1959,1960)$ and Jones and Shattock (1960) could not demonstrate the presence of the antigen in cell-wall fractions of group D streptococci. The group-antigen also was not present in $L$-phase variants of group D streptococci (Hijmans, 1962), although it was later found that $L$-phase variants secreted group $D$ antigen into the medium (Smith and Shattock, 1964). However, when the cell walls of normal cells were removed enzymatically, group D antigen was released into solution (Smith and Shattock, 1964). The site of location of the majority of group D antigen, therefore, seems to be at the surface of the protoplast, immediately beneath the cell wall. At least part of the group $D$ antigen is retained by the protoplast membrane upon dissolution of the cellular structure (Slade and Shock- 
man, 1963; Shockman and Slade, 1964); repeated washing of the membrane fraction resulted in progressive release of the antigen. Group $D$ antigen has a similar location in group $Q$ cells (Smith and Shattock, 1964). The group $Q$ antigen, however, is located principally in the cell-wall fraction, as are the 'type' antigens of group D bacteria (Smith and Shattock, 1964). Thus, the group D (and, incidentally, group N-Elliott, 1963) streptococci possess intracellular teichoic acids (group antigens) just beneath the cell wall, while in the other groups the group antigens a re located in the cell wall. In the group $D$, the 'type' antigens are located in the cell walls. Sharpe (1965) suggested a serological typing scheme for all group D streptococci, based on the presence of chemically defined type-specific antigens.

Chemically, the cell exterior of group D streptococci has been noted to contain glucose and galactose in addition to the usual components (Salton, 1953; Cummins and Harris, 1956; Abrams, 1958; Ikawa, 1959; Armstrong et al., 1959; Slade and Slamp, 1962). The glucose may have been a contaminant rather than a normal cell-wall constituent (Curtis and Krause, 1964), although later studies (Bleiweis and Krause, 1965) indicate that glucose is a component of the cell walls of group D streptococci. Group D antigen preparations were found to contain glucose and a-glycerophosphate in polymerized form (Wicken, Elliott and Baddiley, 1963; Wicken and Baddiley, 1963). The differences discussed are shown in Table 3. Other aspects of streptococcal cell-wall structure and synthesis have been reviewed by Perkins (1963) and Krause (1963), while McCarty (1964) and Willers and co-workers (1964) have recently described serological and chemical studies on soluble antigens of streptococci.

Other Possible Taxonomic Approaches

A survey of enterococcins was made recently by Brock, Peacher and Pierson (1963). These workers concluded that bacteriocinogeny would be of little value in 'delineating the grand design of the enterococcus group,' although some relationships were found between the type of bacteriocine produced and the assigned name of the production strain. Furthermore, bacteriocine production was not an admirably stable characteristic of the enterococci; mutants of $\underline{S}$. faecalis var. zymogenes were obtained which had lost or regained bacteriocinogenic properties concomittantly with loss and gain of hemolytic properties (Brock and Davie, 
1963). Deibel et al. (1963; Deibel, 1964a) have discussed hemolytic capacity as a taxonomic tool for differentiation of the enterococci.

Most of the streptococcal bacteriophage studies appearing through 1960 have been reviewed by Groman (1961) and will not be repeated here. Recent attempts to clarify the inter relationships of the enterococci by bacteriophage typing have met with some encouraging results (Brock, 1964). This method of delineating subgroups within the enterococci has promise for the future. Certain other fecal streptococci also contain prophages (Ciucá et al., 1960; Brailsford et al., 1964), but phage-host interrelationships in species other than $\underline{S}$. faecalis and $\underline{S}$. faecium have not been studied extensively.

Transduction of enterococci has not been accomplished (Brock, 1964), so experiments such as those conducted by Ailen, Sandine and Elliker (1963) on S. lactis (see also Sandine et al., 1962) cannot yet be carried out with the fecal streptococci. Possibly a genetic marker other than streptomycin resistance should be used. Transformation has not been reported to occur within the enterococci (Perry and Slade, 1962, 1963), except possibly at a very low frequency (Pakula, 1961). This genetic approach is yielding valuable information regarding certain other streptococci and closely related genera (see also Ravin and De Sa, 1964; Perry and Slade, 1964). The discovery that genetic exchange within some enterococci may be mediated by sexduction (Raycroft and Zimmerman, 1964) opens up anothe $r$ avenue for future study. Likewise, various studies on the utilization of base combinations and fractions of cellular DNA (c.f., Marmur et al. , 1963) will aid in elucidating the interrelationships of the enterococci and other fecal streptococci.

\section{In Conclusion}

Taxonomy of the fecal streptococci, particularly the enterococci, has been dynamic. Several changes have resulted in changed specific epithets for certain strains. At other times, the name assigned to a microorganism has been changed as more information is obtained about it. Gunsalus, Niven and Sherman (1944), for example, discovered that three strains of "S. lactis $R$, " an organism used for the assay of folic acid, possessed group $D$ antigen and was, in

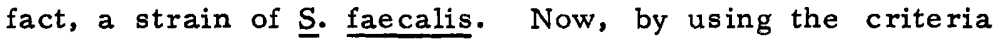
listed in Table 2, the organism would be called $\underline{S}$. faecium 
(Brock, Mosser and Peacher, 1963) or S. faeciumvar. durans (Deibel et al. , 1963; Wyatt and Hartmann, unpublished data). The name of another, more infamous, strain of enterococcus has also been changed several times. Linden, Turner and Thom (1926) isolated a "․․ lactis type" of bacterium from cheese that purportedly had caused an outbreak of food poisoning. This organism was found to be $\underline{S}$. faecalis by Sherman, Smiley and Niven (1943), but is now considered to be quite typical of $\underline{S}$. faecium (Deibel and Silliker, 1963). Changes such as these may be confusing to many investigators, but we hope that each change represents progress in taxonomy of this important group of bacteria.

\section{LITERATURE CITED}

Abrams, A. 1958. O-acetyl groups in the cell wall of Streptococcus faecalis. Jour. Biol. Chem. 230:949-959. Allen, L. K., W. E. Sandine and P.R. Elliker. 1963. Transduction in Streptococcus lactis. Jour. Dairy Res. 30: $351-357$.

Andrewes, F.W. and T.J. Horder. 1906. A study of the streptococci pathogenic for man. Lancet 2:708-713, 775-782 and 852-855.

Armstrong, J.J., J. Baddiley, J.G. Buchanan, A. L. Davison, M. V. Keleman and F.C. Neuhaus. 1959. Teichoic acids from bacterial cells. Nature 184:247-248.

Barnes, E. M. 1956a. Methods for the isolation of faecal streptococci (Lancefield group D) from bacon factories. Jour. Appl. Bact. 19:193-203.

- 1956b. Tetrazolium reduction as a means of differentiating Streptococcus faecalis from Streptococcus faecium. Jour. Gen. Microbiol. 14:57-68.

- 1964. Distribution and properties of serological types of Streptococcus faecium, Streptococcus durans and related strains. Jour. Appl. Bact 27:461-470. and $M$. Ingram. 1955. The identity and origin of faecal streptococci in canned hams. Ann. Inst. Pasteur, Lille 7:115-119.

Bartley, C. H. and L.W. Slanetz. 1960. Types and sanitary significance of fecal streptococci isolated from feces, sewage and water. Am. Jour. Publ. HIth. 50:1545-1552.

Bleiweis, A.S., W.W. Karakawa, and R. M. Krause. 1964. Improved technique for the preparation of streptococcal cell walls. Jour. Bact. 88:1198-1200. 
and R. M. Krause. 1965. The cell walls of group D streptococci. I. The immunochemistry of the type 1 carbohydrate. Jour. Exptl. Med. 122:237-249.

Brailsford, M. D. , J. C. Adams, J.A. Gazaway, P.A. Hartman, and N. L. Jacobson. 1964. Isolation of bacteriophages from the bovine rumen. (unpublished)

Breed, R.S., E.G.D. Murray and N. R. Smith. 1957. Bergey's Manual of Determinative Bacteriology. 7th ed. Williams and Wilkins Co., Baltimore, Maryland.

Brock, T.D. 1964. Host range of certain virulent and temperate bacteriophages attacking group D streptococci. Jour. Bact. 88:165-171.

and J.M. Davie. 1963. Probable identity of a group D hemolysin with a bacteriocine. Jour. Bact. 86:708712 .

, J. Mosser and B. Peacher. 1963. The inhibition by streptomycin of certain streptococcus bacteriophages, using host bacteria resistant to the antibiotic. Jour. Gen. Microbiol. 33:9-22.

, B. Peacher and D. Pierson. 1963. Survey of the bacteriocines of enterococci. Jour. Bact. 86:702-707.

Buchanan, R.E. 1958. Microbiological literacy. Bact. Rev. 22:204-215.

Burkwall, M.K. and P. A. Hartman. 1964. Comparison of direct plating media for the isolation and enumeration of enterococci in certain frozen foods. Appl. Microbiol. 12:18-23.

Ciucă, M., C. Baldovin-Agapi, F. Mihalco, I. Beloiu, and I. Caffé. 1959. Phage-streptococci ecosystems. Attempts to lysotype streptococci of the D group. Arch. Roumaines Pathol. Expt1. 18:519-526.

Colobert, L. 1962. L'espece Streptococcus faecalis et sa valeur en tant que témoin de pollution fécale. Rev. des Corps de Santé des Armées 3, suppl. 3:617-632. and $\mathrm{H}$. Blondeau. 1962a. L'espece Streptococcus faecalis. I. E'tude de l'homogénéité par la méthode Adansonnienne. Ann. Inst. Pasteur 103:345-362. and - 1962b. L'espece Streptococcus faecalis.

III. La répartition différente des divers biotypes dans

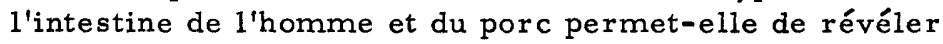
$1^{\prime}$ origine humaine d'une contamination des semi-conserves de viande de porc? Ann. Inst. Pasteur 103:707-715. and P. Morelis. 1958. Inopportunité de la division de

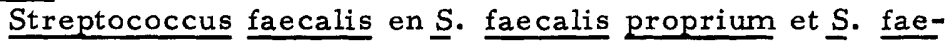
cium. Proc., VIIth Intl. Congr. Microbiol., Stockholm, Sweden, pp. 437-438. 
Cooper, K.E. and F.M. Ramadan. 1955. Studies in the differentiation between human and animal pollution by means of faecal streptococci. Jour. Gen. Microbiol. 12:180-190.

Cummins, C.S. and H. Harris. 1956. The chemical composition of the cell wall in some Gram-positive bacteria and its possible value as a taxonomic character. Jour. Gen. Microbiol. 14:583-600.

Curtis, S. N. and R. M. Krause. 1964. Immunochemical studies on the specific carbohydrate of group $\mathrm{G}$ streptococci. Jour. Exptl. Med. 119:997-1004.

Defayolle, M. and L. Colobert. 1962. L'espece Streptococcus faecalis. II. Etude de l'homogénéité par l'analyse factorielle. Ann. Inst. Pasteur 103-505-522.

Deibel, R. H. 1960. Arginine as an energy source for the growth of Streptococcus faecalis. Bact. Proc. pp. $163-164$.

- 1964a. The group D streptococci. Bact. Rev. 28:330-366.

- 1964b. Utilization of arginine as an energy source for the growth of Streptococcus faecalis. Jour. Bact. 87:988-992.

, J. B. Evans and C.F. Niven, Jr. 1958. Lipoic acid requirement for anaerobic utilization of pyruvate as an energy source by Streptococcus faecalis. Bact. Proc. p. 114.

and - 1959. Occurrence and significance of enterococci in hams. Ann. Rept., American Meat Inst. Found., Bull. 42:15.

D. Lake and C.F. Niven, Jr. 1959. Occurrence and significance of enterococci in hams. Ann. Rept., American Meat Inst. Found., Bull. 42:36. and - 1963. Physiology of the enterococci as related to their taxonomy. Jour. Bact. 86:1275-1282.

and C.F. Niven, Jr. 1960. Lipoic acid and the fermentation of serine and malate by Streptococcus faecalis. Bact. Proc. p. 164.

and - 1964. Pyruvate fermentation by Streptococcus faecalis. Jour. Bact. $88: 4-10$. and J.H. Silliker. 1964. Food-poisoning potential of the enterococci. Jour. Bact . 85:827-832

Dible, J.H. 1921. The enterococcus and the faecal streptococci: their properties and relations. Jour. Pathol. and Bact. 24:3-35. 
Dunican, L. K. and H.W. Seeley. 1962. Starch hydrolysis by Streptococcus equinus. Jour. Bact . 83:264-269.

Elliott, S. D. 1959. Group and type-specific polysaccharides of group D streptococci. Nature 184:1342.

- 1960. Type and group polysaccharides of group D streptococci. Jour. Exptl. Med. 111:621-630.

- 1963. Teichoic acid and the group antigen of lactic streptococci (group N). Nature 200:1184-1185.

Engelbrecht, M.A. 1935. The biological characters of the streptococcus commonly associated with mastitis (Str. agalactiae). Cornell Vet. 25:313-333.

Evans, A.C. and A. L. Chinn. 1947. The enterococci: with special reference to their association with human disease. Jour. Bact. 54:495-512.

Ferraro, F.M. 1960. Studies upon the distribution and identification of Streptococcus faecalis and Streptococcus faecium. Diss. Abstr. 20:4243.

Frost, W. D. and M.A. Engelbrecht. 1940. The streptococci. Willdof Book Co., Madison, Wisconsin.

Fuller, R. and L. G. M. Newland. 1963. The serological grouping of three strains of Streptococcus equinus. Jour. Gen. Microbiol. 31:431-434.

Graham, N. C. and E. O. Bartley. 1939. Some observations on the classification of enterococci. Jour. Hyg. 39:538552.

Graudal, H. 1957a. The classification of motile streptococci within the enterococcus group. Acta Pathol. Microbiol. Scand. 41:403-410.

- 1957b. On the serology of motile streptococci. Acta Pathol. Microbiol. Scand. 41:397-402.

Groman, N. B. 1961. Phage-host relationships in some genera of medical significance. Ann. Rev. Microbiol. 15:153-176.

Gunsalus, I. C., C. F. Niven, J r., and J. M. Sherman. 1944. The identification of "Streptococcus lactis $R$ " as a strain of Streptococcus faecalis. Jour. Bact. 48:611.

Guthof, 0. 1955. Über eine neue serologische Gruppe alphahämolytischer Streptokokken (Serologische Gruppe Q). Zentralbl. Bakteriol. , Parasitol., Infekt. u. Hyg., Abt. I, Orig. 164:60-63.

Hare, R. and W. R. Maxted. 1935. The classification of haemolytic streptococci from the stools of normal pregnant women and of cases of scarlet fever by means of precipitin and biochemical tests. Jour. athol. and Bact. 41:513:520. 
Hartman, P.A., G.W. Reinbold and D.S. Saraswat. 1965. Indicator organisms-a review. II. Food poisoning potential of the fecal streptococci. Jour. Milk Food Technol. 28:344-350.

Hartsell, S. E. and J.H. Caldwell. 1961. Lysozyme and the differentiation of group D streptococci. Proc., Second Intl. Symp. on Fleming's Lysozyme, Milan, Italy.

Hauduroy, P. 1953. Dictionnaire des Bactéries Pathogenes. Masson et Cie, Paris, France.

Hijmans, W. 1962. Absence of the group-specific and the cell-wall polysaccharide antigen in L-phase variants of group D streptococci. Jour. Gen. Microbiol. 28:177-179.

Horie, S. 1959. Studies on enterococci as pollution indices of food and drink. II. Subdivision of enterococci on the basis of the fermentation tests. Bull. Japanese Soc. Sci. Fisheries 25:488-496.

- 1961. The classification of enterococci on the basis of fermentation and nutritional requirements. Jour. Tokyo Univ. Fisheries 47:281-288.

Houston, T. 1936. Enterococci. Proc., IInd Intl. Congr. Microbiol., London, England. 141-142.

Ikawa, M. 1961. The partial chemical degradation of the cell walls of Lactobacillus plantarum, Streptococcus faecalis and Lactobacillus casei. Jour. Biol. Chem. 236:1087-1092.

Isaacs, A. and J.M. Scouller. 1948. Catalase production by Gram-positive cocci: A simple test for differentiating enterococci from micrococci. Jour. Pathol, and Bact. 60:135-136.

Jones, D. and P. M. F. Shattock. 1960. The location of the group antigen of group D streptococcus. Jour. Gen. Microbiol. 23:335-343.

Kenner, B. A., H.F. Clark and P.W. Kabler. 1960. Fecal streptococci. II. Quantification of streptococci in feces. Am. Jour. Publ. Hlth. 50:1553-1559.

Kereluk, K. 1959. Studies on the bacteriological quality of frozen meat pies. III. Identification of enterococci isolated from frozen meat pies. Appl. Microbiol. 7:324-326.

Krantz, G. E. and H. W. Dunne. 1965. An attempt to classify streptococic isolates from domestic animals. Amer. Jour. Vet. Res. 26:951-959.

Krause, R. M. 1963. Symposium on relationship of structure of microorganisms to their immunological properties. IV. Antigenic and biochemical composition of hemolytic streptococcal cell walls. Bact. Rev. 27:369380 . 
Kunter, E. 1963. Die Streptokokken-Präzipitation im AgarGel auf dem Objektträger. Zentrabl. Bakteriol., Parasitol., Infekt. u. Hyg., Abt. I, Orig. 188:190-194.

Lake, D.E., R. H. Deibel, and C.F. Niven, Jr. 1957. The identity of Streptococcus faecium. Bact. Proc. p. 13.

Lancefield, R. C. 1933. A serological differentiation of human and other groups of hemolytic streptococci. Jour. Exptl. Med. 57:571-595.

- 1941. Specific relationship of cell composition to biological activity of hemolytic streptococci. Harvey Lectures 36:251-290. and R. Hare. 1935. The serological differentiation of pathogenic and non-pathogenic strains of hemolytic streptococci from parturient women. Jour. Exptl. Med. 61: 335-349.

Langston, C. W. , J. Gutierrez, and C. Bouma. 1960. Motile enterococci (Streptococcus faecium var. mobilis var. n.) isolated from grass silage. Jour. Bact. 80: 714-718.

Linden, B. A., W. R. Turner and C. Thom. 1926. Food poisoning from a streptococcus in cheese. Publ. . Hlth. Repts. 41:1647-1652.

London, J. and M. D. Appleman. 1962. Oxidative and glycerol metabolism of two species of enterococci. Jour. Bact. 84:597-598.

Long, H. F. and B. W. Hammer. 1936. Classification of the organisms important in dairy products. I. Streptococcus liquefaciens. Iowa State Coll. Agr. Exp. Sta. Bull. 206:217-251.

MacCallum, W. G. and T.W. Hastings. 1899. A case of acute endocarditis caused by Micrococcus zymogenes (Nov. Spec.) with a description of the microorganism. Jour. Expt1. Med. 4:521-534.

Mannweiler, E. 1955. Beiträge zur Diagnostik der Enterococcen. Z. tropenmed. Parasitol. 6:63-72.

Marmur, J., S. Falkow and M. Mandel. 1963. New approches to bacterial taxonomy. Ann. Rev. Microbiol. 17:329-372.

Mattick, A.T.R. 1949. The lactic streptococci (including their antibiotic activity). . Proc. , IVth Int1. Congr. Microbiol., Copenhagen, Denmark. 519-520.

McCarty, M. 1964. The role of d-alanine in the serological specificity of group A streptococcal glycerol teichoic acid. Proc. Nat. Acad. Sci. 52:259-265. 
Medrek, T.F. and E. M. Barnes. 1962a. The physiological and serological properties of Streptococcus bovis and related organisms isolated from cattle and sheep. Jour. App1. Bact. 25:169-179. and - $1962 \mathrm{~b}$. The influence of the growth medium on the demonstration of a group $D$ antigen in faecal streptococci. Jour. Gen. Microbiol. 28:701-709. Mieth, H. 1960. Untersuchungen ther das Vorkommen von Enterokokken bei Tieren und Menschen. I. Thr Vorkommen in Darm von ge sunden Schlachts chweinen. Zentralbl. Bakteriol., Parasitenk., Infekt. u. Hyg., Abt. I, Orig. 179:456-482.

- 1961. Untersuchungen über das Vorkommen von Enterokokken bei Tieren und Menschen. II. Ihr Vorkommen in Stuhlproben von gesunden Menschen. Zentralbl. Bakteriol., Parasitenk., Infekt. u. Hyg., Abt. I, Orig. 183:68-89.

Morelis, P. and L. Colobert. 1958. Un milieu sélectif permettant l'identification et le dénombrement rapides de Streptococcus faecalis. Ann. Inst. Pasteur 95:568-587.

Mossel, D.A.A., H. M. van Diepen, and A.S. deBruin. 1957. The enumeration of faecal streptococci in foods, using Packer's crystal violet sodium azide blood agar. Jour. Appl. Bact. 20:265-272.

Mundt, J. O. 1963. Occurrence of enterococci on plants in a wild environment. Appl. Microbiol. 11:141-144.

Niven, C.F. Jr., R. C. Lancefield, R.H. Deibel, I. C. Gunsalus, and P.A. Hartman, 1964. The enterococci. Bact. Proc. p. xvi-xviii.

- 1963. Microbial indexes of quality: fecal streptococci. In: Slanetz, L. W., C. O. Chicester, A. R. Gaufin and Z.J. Ordal. (Eds.) Microbial Quality of Foods. Academic Press, N. Y.

- K. L. Smiley and J. M. Sherman. 1942. Streptococcus salivarius in the human intestine. Jour. Bact. 43: 113-114.

Orla-Jensen, S. 1919. The Lactic Acid Bacteria. A.F. Host and Son, Copenhagen, Denmark.

Pakula, R. 1961. Interspecific transformation as a means of determining genetic relationships in streptococci. Acta Microbiol. Polonica 10:249-254.

Papavassiliou, J. 1962. Species differentiation of group D streptococci. Appl. Microbiol. 10:65-69.

Perkins, H. R. 1963. Chemical structure and biosynthesis of bacterial cell walls. Bact. Rev. 27:18-55. 
Perry, D. and H. D. Slade. 1962. Transformation of streptococci to streptomycin resistance. Jour. Bact. 83:443449.

and - 1963. Optimal conditions for the transformation of streptococci. Jour. Bact. 85:636-642. and - 1964. Intraspecific and interspecific transformation in streptococci. Jour. Bact. 88:595-601.

Perry, K. D. and C.A.E. Briggs. 1955. A common type antigen in streptococci of groups D and E. Jour. Pathol. and Bact. 70:546. , L. G. M. Newland and C.A.E. Briggs. 1958. GroupD rumen streptococci with type antigens of group N. Jour. Pathol. and Bact. 76:589-590.

Prescott, J.M., W.T. Williams and R.S. Ragland. 1959. Influence of nitrogen source on growth of Streptococcus bovis. Proc. Soc. Exptl. Biol. Med. 102:490-493.

Ravin, A. W. and J.D.H. De Sa. 1964. Genetic linkage of mutational sites affecting similar characters in pneumococcus and streptococcus. Jour. Bact. 87:86-96.

Raycroft, R.E. and L. N. Zimmerman. 1964. New mode of genetic transfer in Streptococcus faecalis var. liquefaciens. Jour. Bact. 87:799-801.

Safford, C.E., J.M. Sherman and H. M. Hodge. 1937. Streptococcus salivarius. Jour. Bact. 33:263-274.

Salton, M.R.J. 1953. Studies of the bacterial cell wall. IV. The composition of the cell walls of some gram-positive and gram-negative bacteria. Biochim. Biophys. Acta $10: 512-523$.

Sandine, W.E., P.R. Elliker, L. K. Allen, and W. C. Brown. 1962. Symposium on lactic starter cultures. II. Genetic exchange and variability in lactic streptococcus starter organisms. Jour. Dairy Sci. 45:1266-1271.

Seelemann, M. 1964. Biologie der Streptokokken. Hans Carl, Nürnberg.

and O. Carstens. 1951. Die serologische Zugehörigkeit des Sc. bovis und sog. atypischer Enterokokken zur Gruppe D. Kieler Milchwirts chaftliche Forsch. 3:431442.

and G. Obiger. 1964. Zur Diagnose und Nomenklatur der Streptokokken, insbesondere der vergrünenden Arten. Zentralbl. Bakteriol., Parasitenk., Infekt. u. Hyg., Abt. I, Orig. 192:434-447.

Severi, R. 1942. Una nouva specie di enterococco $1^{\prime}$ "enterococcus glycerinaceus." Giorn. Batteriol., Virol., Immunol. 28:422-446. 
Sharpe, M.E. 1952. Occurrence of a common type antigen in streptococci of groups D and N. Jour. Gen. Microbiol. 7:192-199.

- 1965. Serological types of Streptococcus faecalis and its varieties and their cell wall type antigen. Jour. Gen. Microbiol. 36:151-160.

and B. G. Fewins. 1960. Serological typing of strains of Streptococcus faecium and unclassified group D streptococci isolated from canned hams and pig intestines. Jour. Gen. Microbiol. 23:621-630. and P.M.F. Shattock. 1952. The serological typing of group D streptococci associated with outbreaks of neonatal diarrhoea. Jour. Gen. Microbiol. 6:150-165.

Shattock, P.M.F. 1949a. The faecal streptococci. Proc., 12th Intl. Dairy Congr. 2:598-604.

- 1949b. The streptococci of group D; the serological grouping of Streptococcus bovis and observations on serologically refractory group D strains. Jour. Gen. Microbiol. 3:80-92.

- 1955. The identification and classification of Streptococcus faecalis and some associated streptococci. Ann. Inst. Pasteur, Lille 7:95-100.

- 1962. Enterococci. In: Ayres, J. C. , A. A. Kraft, H.E. Snyder and H.W. Walker. (Eds.) Chemical and Biological Hazards in Food. Iowa State University Press, Ames, Iowa. and A. T.R. Mattick. 1943. The serological grouping of Streptococcus lactis ( $g$ roup $N$ ) and its relationship to Streptococcus faecalis. Jour. Hyg. 43:173-188.

Sherman, J.M. 1937. The streptococci. Bact. Rev. $1: 3-97$.

- 1938. The enterococci and related streptococci.

Jour. Bact. 35:81-93.

, J. C. Mauer and P. Stark. 1937. Streptococcus

faecalis. Jour. Bact. 33:275-282. , C.F. Niven, Jr., and K. L. Smiley. 1943. Streptococcus salivarius and other non-hemolytic streptococci of the human throat. Jour. Bact. 45:249-263.

, K. L. Smiley and C.F. Niven, Jr. 1943. The identity of a streptococcus associated with food poisoning from cheese. Jour. Dairy Sci. 26:321-323. and H. U. Wing. 1935. An unnoted hemolytic streptococcus as sociated with milk products. Jour. Dairy Sci. $18: 656-660$. and 1937. Streptococcus durans n. sp. Jour. Dairy Sci. 20:165-167. 
Shockman, G. D. and H. D. Slade. 1964. The cellular location of the streptococcal group D antigen. Jour. Gen. Microbiol. 37:297-305.

Skadhauge, K. 1950. Studies on Enterococci with Special Reference to the Serological Properties. Einar Munksgaards Forlag, Copenhagen, Denmark.

Slade, H. D. and G.D. Shockman. 1963. The protoplast membrane and the D antigen of Streptococcus faecalis. Bact. Proc. p. 46.

and W.C. Slamp. 1962. Cell-wall composition and the grouping antigens of streptococci. Jour. Bact. 84: 345-351.

Slanetz, L. W. and C. H. Bartley. 1957. Numbers of enterococci in water, sewage and feces determined by the membrane filter technique with an improved medium. Jour. Bact. 74:591-595. and - 1964. Detection and sanitary significance of fecal streptococci in water. Am. Jour. Publ. Hlth. 54:609-614.

Smith, D. G. and P.M.F. Shattock. 1962. The serological grouping of Streptococcus equinus. Jour. Gen. Microbiol. $29: 731-736$.

and - 1964. The cellular location of antigens in streptococci of groups $D, N$, and $Q$. Jour. Gen. Microbiol. 34:165-175.

Smith, F.R., C.F. Niven, Jr., and J.M. Sherman. 1938. The serological identification of Streptococcus zymogenes with the Lancefield group D. Jour. Bact. 35:425-428.

Sokal, R. R. and P.H.A. Sneath. 1963. Principles of Numerical Taxonomy. W.H. Freeman and Co., San Francisco, California.

Sternberg, G. M. 1892. A Manual of Bacteriology. William Wood and Co., New York, N. Y.

Stewart, F.S. and J.D. McKeever. 1963. Serological definition of Lancefield group K. Jour. Pathol. and Bact. 85:383-388.

Thiercelin, M.E. 1899. Sur un diplocoque saprophyte de 1 'intestin susceptible de devenir pathogène. Compt. Rend. Soc. Biol. 51:269-271.

Thoms on, D. and R. Thoms on. 1928-29. The pathogenic streptococci. Ann. Pickett-Thomson Res. Lab. 4:1-494.

Whittenbury, R. 1963. The use of soft agar in the study of conditions affecting utilization of fermentable substrates by lactic acid bacteria. Jour. Gen. Microbiol. 32:375384. 
- 1965a. The differentiation of Streptococcus faecalis

and S. faecium. Jour. Gen. Microbiol. 38:279-287.

- 1965b. A study of some pediococci and their relationship to Aerococcus viridans and the enterococci. Jour. Gen. Microbiol. 40:97-106.

Wicken, A.J. and J. Baddiley. 1963. Structure of intracellular teichoic acids from group D streptococci. Biochem. Jour. 87:54-62.

S. D. Elliott, and J. Baddiley. 1963. The identity of streptococcal group D antigen with teichoic acid. Jour. Gen. Microbiol. 31:231-239.

Willers, J.M. N. , M.F. Michel, M.J. Sysma and K. C. Winkler. 1964. Chemical analysis and inhibition reactions of the group and type antigens of group $F$ streptococci. Jour. Gen. Microbiol. 36:95-105.

, H. Ottens and M.F. Michel. 1965. Immunochemical relationship between streptococcus $M G, F$ III and Streptococcus salivarius. Jour. Gen. Microbiol. 37:45 $\overline{25-431}$.

Williams, R.E.O. 1956. Streptococcus salivarius (vel hominis) and its relation to Lancefield's group K. Jour. Pathol. and Bact. 72:15-25.

A. Hirch and S. T. Cowan. 1953. Aerococcus, a new bacterial genus. Jour. Gen. Microbiol. 8:475-480. and A. T. Wilson. 1963. Minutes of the third meeting. Subcommittee on the taxonomy of the streptococci and pneumococci. Intl. Bull. Bacteriol. Nomen. Taxon. 13:111-118.

Wolin, M. J., G. B. Manning and W. O. Nelson. 1959. Ammonium salts as a sole source of nitrogen for the growth of Streptococcus bovis. Jour. Bact. 78:147. 
